HoST - Journal of History of Science and Technology

Vol. 15, no. 2, Dec 2021, pp. 17-33

10.2478/host-2021-0011

SPECIAL ISSUE

BUILDING SITES, CRAFTING KNOWLEDGE

\title{
Production and Circulation of Technical Knowledge on Building Sites at the End of the Eighteenth Century
}

\author{
Valérie Nègre \\ Université Paris 1 Panthéon Sorbonne, France \\ Valerie.Negre@univ-paris1.fr, valerie-negre@wanadoo.fr
}

\begin{abstract}
This article aims to shed light on the exchange of technical knowledge between architects, master craftsmen and workmen on building sites at the end of the eighteenth century. In the Age of Enlightenment, major building sites were places where a large number of skilled practitioners of various ranks met (engineers, architects, contractors, experts, craftsmen). These were therefore places where the exchange of knowledge and know-how occurred but also places of struggle for power and knowledge. The article examines these exchanges and struggles using the case study of the building site for the dome of the Halle au Blé in Paris (1782-1783).
\end{abstract}

Keywords: building sites; artisan; architect; contractor; technical knowledge 


\section{Introduction}

This article aims to shed light on the production and circulation of technical knowledge between architects, master craftsmen and workmen on building sites at the end of the eighteenth century. Compared to the workshop where operations were carried out by men belonging to the same trades, and where artefacts changed hands according to a determined spatial and temporal sequence, building sites were itinerant places where a wide range of craftsmen (masons, carpenters, joiners, etc.) and professionals (architects, surveyors, measurers, engineers, etc.) interacted. The task of each practitioner differed on every site, depending on the type and scale of the building, the location of the construction, the materials chosen and other circumstances.

Because of these characteristics, several scholars have underlined the fact that building sites were places of innovation and knowledge transfer. Pamela O. Long has suggested that building sites that were the focus of interest on the part of the elite, and where particular technical process that required practical knowledge were tested, could be considered as trading zones, that is to say arenas in which "substantive and reciprocal communication" occurred between individuals who were "artisanally trained and learned individuals." ${ }^{1}$ Taking the example of the transport of obelisks in Rome in the late sixteenth century she showed interchange between learned and technical cultures based on reading, writing, designing and fabricating physical things.

In contrast, adopting the concept of non-simultaneity (Ungleichzeitigkeit), Christoph Rauhut has shown that if the building process was characterized by the simultaneous existence of different people, practices and objects, these people and objects did not automatically interact. ${ }^{2}$ Rauhut rightly observes that in the nineteenth century many innovations and transformations changed building construction-its agents, practices and objects—but a number of aspects remained unchanged. The vernacular processes co-existed with the new. Time act as a parameter for differentiation. If we wish to consider innovation and knowledge transfer, we must also pay close attention to the juxtaposition of practices that enrich and sometimes contradict the process of modernisation.

\footnotetext{
${ }^{1}$ For the concept of trading zones developed by Peter Galison from the work of anthropologist Michael T. Taussig, see, Pamela O. Long, "Trading Zones in Early Modern Europe," Isis 106, no. 4 (2015): 8407. And also Pamela O. Long, "Multi-tasking 'pre-professional' architect/engineers and other bricolagic practitioners as key figures in the elision of boundaries between practice and learning in sixteenthcentury Europe; some Roman examples," in The Structures of Practical Knowledge, ed. Matteo Valleriani, 223-46 (Springer: Dordrecht, 2017).

${ }^{2}$ The concept of non-simultaneity is nowadays understood in German-speaking academia as an intellectual tool to recognize practices and ideas that contradicted the formative process of modernization. See EikeChristian Heine and Christoph Rauhut, eds., Producing Non-Simultaneity. Construction Sites as Places of Progressiveness and Continuity (London and New York: Routledge, 2018).
} 
Similarly, but with a more social approach, Chandra Mukerji has drawn attention to conflicts between the different actors. ${ }^{3}$ Studying the notable case of the Canal du Midi, she shows how the authority of the entrepreneur Pierre-Paul Riquet (1609-1680) was purposely weakened by the multiplication of subcontractors overseen by the appointees of the minister Jean-Baptiste Colbert to assert the sovereignty of Louis XIV.

An invaluable source written by the French architect Jacques Molinos titled Note des opérations successivement faites pour la construction de la calotte de la halle aux grains (Note on the operations successively made for the construction of the dome of the corn exchange), relating the construction of the dome of the Halle au Blé in Paris (between 1782-1783) offers the opportunity to contribute to this on-going discussion concerning the production and the circulation of technical knowledge on building sites. The dome is well known to historians of architecture. ${ }^{4}$ It covered the immense courtyard of the Halle au Blé built by the architect Nicolas Le Camus de Mézières (1721-1789) some twenty years earlier. As soon as it was completed, the wooden structure was considered a work of great hardiesse (boldness) for its extraordinary dimensions, close to those of the largest domes built in Europe, as well as for its construction method. To solve the technical problem posed by roofing the large circular courtyard, the architects Jacques Molinos (1743-1831) and Jacques Guillaume Legrand (17531807) proposed in 1782 to use an old technique of carpentry with assembled wooden planks, first described by the architect and former stone mason Philibert De l'Orme in his Nouvelles inventions pour bien bastir et a petits frais (New inventions to build well and at low cost, 1561). ${ }^{5}$ For the execution of this structure, they called upon the master joiner André Jacob Roubo (1739-1791), well known in these times for his treatise on joinery published in the prestigious Description des arts et métiers (Description of arts and crafts) collection.

Before commenting on this document, I will begin by recalling the context in which this construction took place, then I will focus on operations about which historians often lack information: the construction and the lifting (levage) of the scaffolding, measurements and verifications, the tracing of full-scale drawings on the site, and the body performance of the workers. The detailed chronology of the works reveals a division between design and execution that is less clear than one might think. Solutions are brought in the course of construction

\footnotetext{
${ }^{3}$ Chandra Mukerji, Impossible Engineering: Technology and territoriality on the Canal du Midi (Princeton: Princeton University Press, 2009).

${ }^{4}$ See Marc Deming, La Halle au blé de Paris, 1762-1813 (Brussels: AAM, 1984) and Dora Wiebenson, "The Two Domes of the Halle au Blé in Paris," Art Bulletin LV, no. 2 (1973): 262-79. Valérie Nègre, "La contribution des artisans au rétablissement de la charpente de Philibert De l'Orme au XVIIIe siècle," in Philibert De l'Orme. Un architecte dans l'histoire, ed. Frédérique Lemerle and Yves Pauwels, 231-42 (Turnhout: Brepols, 2016).

5 See Jean-Marie Pérouse de Montclos, "La Charpente à la Philibert De l'Orme" in Les Chantiers de la Renaissance, ed. André Chastel and Jean Guillaume, 27-50 (Paris: Picard, 1991), and Pérouse de Montclos, "Présentation des traités," Philibert de L’Orme, Traités d'architecture (Paris: Laget, 1988), 4-7.
} 
to solve problems which had not been anticipated. These solutions found by the masters and sometimes the workers make the structure a collective work that it is difficult to attribute to a single designer. The construction site appears as a place offering possibilities to distinguish oneself by inventions and body performance. The "Note" documents a transfer of knowledge from craftsmen to architects, but there is no evidence here of reciprocal communication.

\section{Political background to the building}

It should be noted that the building site of the corn exchange was out of the common. The construction of the dome was a major undertaking because of the function of the building and the size of the structure to be built. Although the Halle au Blé (built between 1763-1766) was a utilitarian building, erected in the busy market district north of the Seine, it was no ordinary one. It stored the grain used to bake the capital's bread, the staff of life for the people of Paris. It was also a remarkable building. First, because it looked like a monument; second, because it was technically innovative. The corn exchange had the noble aspect of an amphitheatre built of ashlar masonry and girded with arcades (Figure 1). Its fully vaulted brick structure was fireproof. By enabling the construction of such a building, the King, Louis XVI, and the senior municipal official, the Provost of the Merchants (Prévôt des marchands), had given the capital a building of value to all its citizens. It was economically useful and reliable and was considered in 1771 to be a "truly patriotic" monument "worthy of the Romans."

Twenty years later, adding a dome to it was also no ordinary task (Figure 2). The dome had to cover a circular courtyard with a diameter of 39 metres (120 feet 4 inches) comparable to that of the Pantheon in Rome. At that time, Paris had no cupola of similar size. In addition to this exceptional size, it had to be supported by the existing walls, which had not been designed to bear such a large vault. To successfully span such an area was a further opportunity for the municipal and royal administrations to demonstrate their ability to undertake major projects for the welfare of the people of Paris. The building site was visited in person at least three times by the Lieutenant général de police (Lieutenant General of Police), an officer charged by the King to ensure the capital's regular food supply and its efficient material, moral and spiritual functioning — clear evidence of the political nature of the building. Louis XVI himself ordered the model of the dome to be brought out to Versailles to be presented to him, and kept it for a while in his private appartements.

\footnotetext{
${ }^{6}$ George Louis Le Rouge, Curiosités de Paris, de Versailles, Marly, Vincennes, Saint-Cloud et des environs, (Paris: 1771), vol. I, “La nouvelle Halle au Bled,” 223, 226.
} 

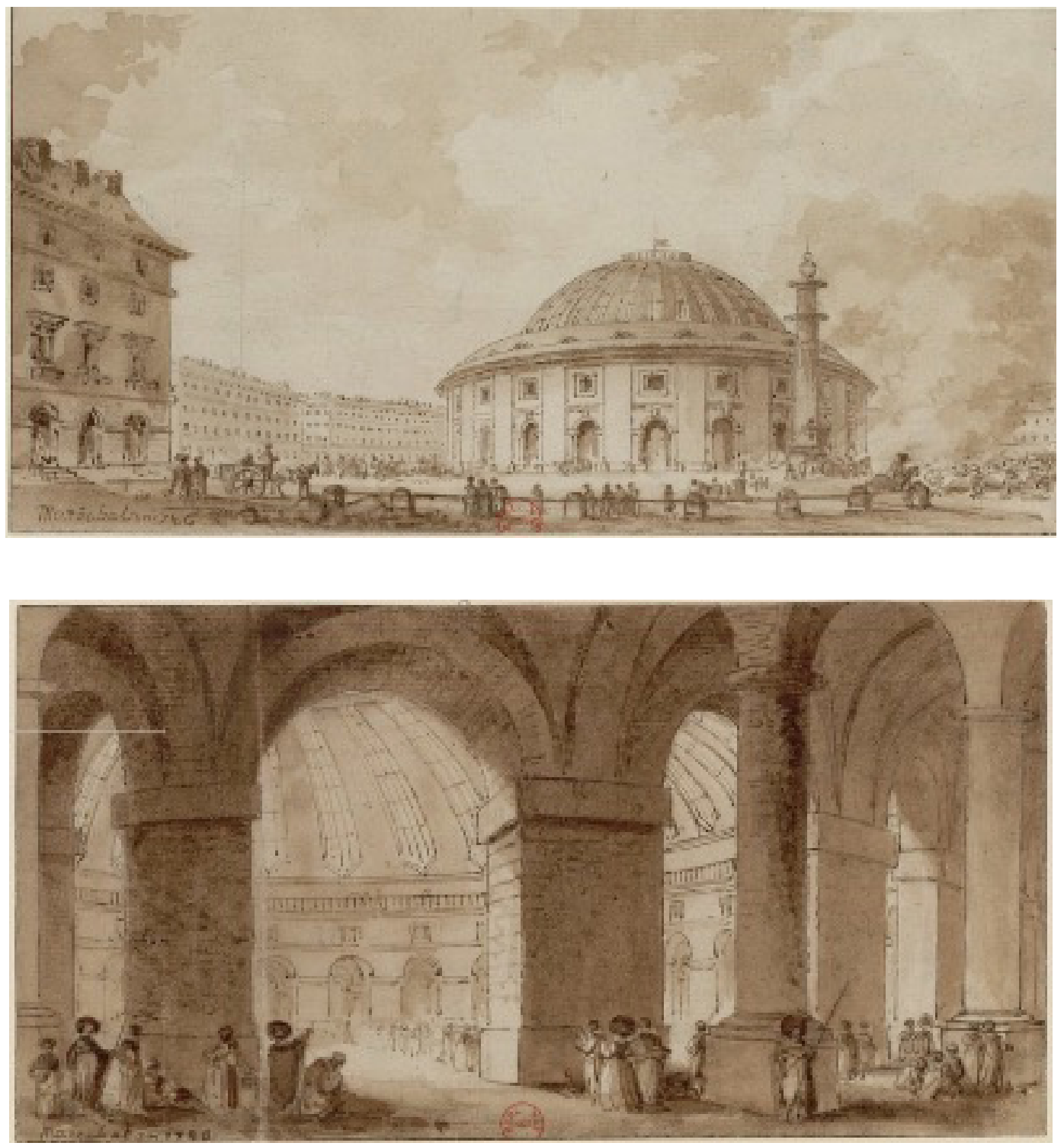

Figure 1 and Figure 2. Jean-Baptiste Maréchal, Outside and inside of the Halle au Blé, 1786, BnF, Reserve FOL-VE-53(F).

The political importance of the project emerges clearly in the arguments developed by the architects in the Mémoire (Memoir) presenting their project. The criteria advanced-utility, economy and safety-were dear to the hearts of the capital's administrators. The aim was to protect the "most valuable foodstuffs" from bad weather. ${ }^{7}$ In terms of economy, the architects

7 [Legrand and Molinos], "Notice sur le procédé de la (nouvelle) charpente de la halle au Bled" n.d., Ms. 
emphasised the savings to be made in materials and money. The process of assembling short, thin pieces of timber had the advantage of not requiring expensive heavy beams. These prime timbers, now in short supply, could be reserved for the strategic sector of the Navy. The light weight of the dome would avoid the cost of reinforcing the existing walls and the use of short pine planks would save one-third of the cost of the frame. ${ }^{8}$

To persuade the Lieutenant général de police, responsible for public safety in Paris, of the solidity of the structure, the project was presented as the "application" of an existing process already experimented with during the Renaissance by a King's architect and reused in several occasions (Figure 3). The architects cleverly presented themselves not as the authors of the building method but as men who would "revive" an old technique that had been forgotten in Paris and with it the admirable work of the architect of Henri II and Catherine de Médicis. They only mentioned a "reasoned and perfected application," without going into details of the improvements. Adapting the procedure to an existing building of such size apparently posed no problems.

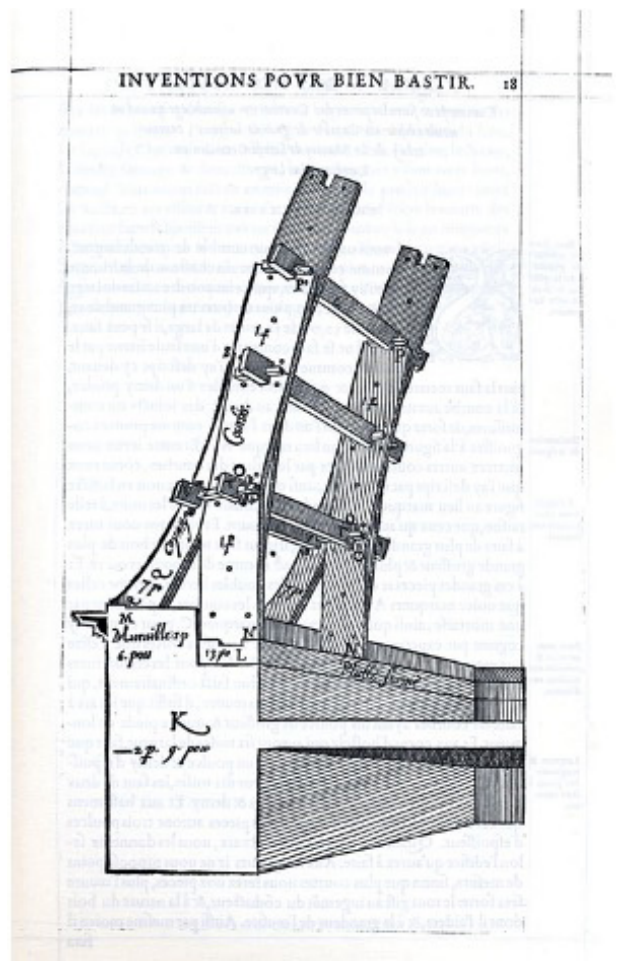

Figure 3. Philibert De l'Orme, Nouvelles inventions pour bien bastir, 1561, p. 18.

CP 4823, Bibliothèque historique de la ville de Paris (hereafter BHVP), Paris.

8 [Legrand and Molinos] "Mémoire sur un Projet de couverture pour la cour de la halle au Bled, proposé à Mr le Lieutenant général de police par Ms Legrand et Molinos architectes,” 1782, Ms. CP 4823, BHVP, Paris. 


\section{The building site: a place of continual invention}

The "Note" consists of eight sheets folded in two, that is to say a total of 32 pages of text, illustrated in the margins with 42 sketches (Figure 4). ${ }^{9}$ It describes 24 weeks' work from the start on 17 July 1782 to completion of the timber frame in early January 1783. It comes with a number of documents (notes, letters, memoranda) belonging to the architect. At first glance, the text resembles a construction site diary. The architect relates the progress of the operations, accidents and visits. But on closer inspection, the narrative is not written in the first person. The actions are expressed without a real subject by impersonal verbs used in the third person or in the infinitive ("having constructed a ruler," "traced the full-scale drawing of the main curves"). If the document reports the way in which the occupations of the craftsmen follow one another in time (in order of appearance: joiners, locksmiths, masons, rubble carrier [gravatiers], mariners [mariniers], carpenters, stonecutters, tilers, roofers), it does not describe the exchanges between the architects, the masters and the journeymen, so that it is not clear who commands, organizes and supervises. We will return to this issue.

Nevertheless, the source shows that the application of the plank structure, albeit a known one, involved adapting and even inventing a number of methods, procedures and tools.

1. Scaffolding. Almost half of the text ( $43 \%$ exactly) and 15 of 42 sketches deal with the construction and the lifting of scaffolding. Barely mentioned in the description of the initial project, the scaffolding turned out to be more difficult to erect than the timber frame itself (Figures 4 and 5). At project stage, the city architect had noted the low cost of scaffolding given in the estimate. The architects' reply to his remark suggests that they were not aware of the problem it posed, or did not wish to mention it. They argued that the scaffolding would be simple, of a sort in common use:

the reason they [the architects] entered a low sum for this item is that their scaffolding is perfectly simple. The assembly of the curved part itself serves to erect it almost entirely, leaving the installation of the lantern. Six or eight pine masts 80 feet high, which they will only need to hire, since they will not notch them, will serve as the central scaffolding, using flanking members (moises) as in the frame itself. The flying scaffolding [not standing on the ground] for repairs will be exactly the sort that they use for ceiling battens (voliges), which albeit really strong, are so simple and generally used that they are not worth describing. ${ }^{10}$

\footnotetext{
9 "Note des opérations successivement faites pour la construction de la calotte de la halle aux grains suivant la méthode de Philibert Delorme commencée le 17 juillet 1782 par Legrand et Molinos architectes," Ms. 32 p., Ms CP 4823, BHVP, Paris.

10 "si la somme qu'ils ont portée [les architectes] pour cet article est très modique c'est que leurs échafauts sont on ne peu plus simples. L'assemblage de la calotte elle même sert pour la monter presque en entier, reste donc la pose de la lanterne. 6 ou 8 mats de sapin de 80 pieds de haut qu'ils ne feront même que louer, puisqu'il ne les entaillerons pas, leur serviront pour faire l'echafaut du milieu en les moisant par le même principe de leur charpente. Les échafauts volants [échafaudages suspendus qui ne s’appuient
} 


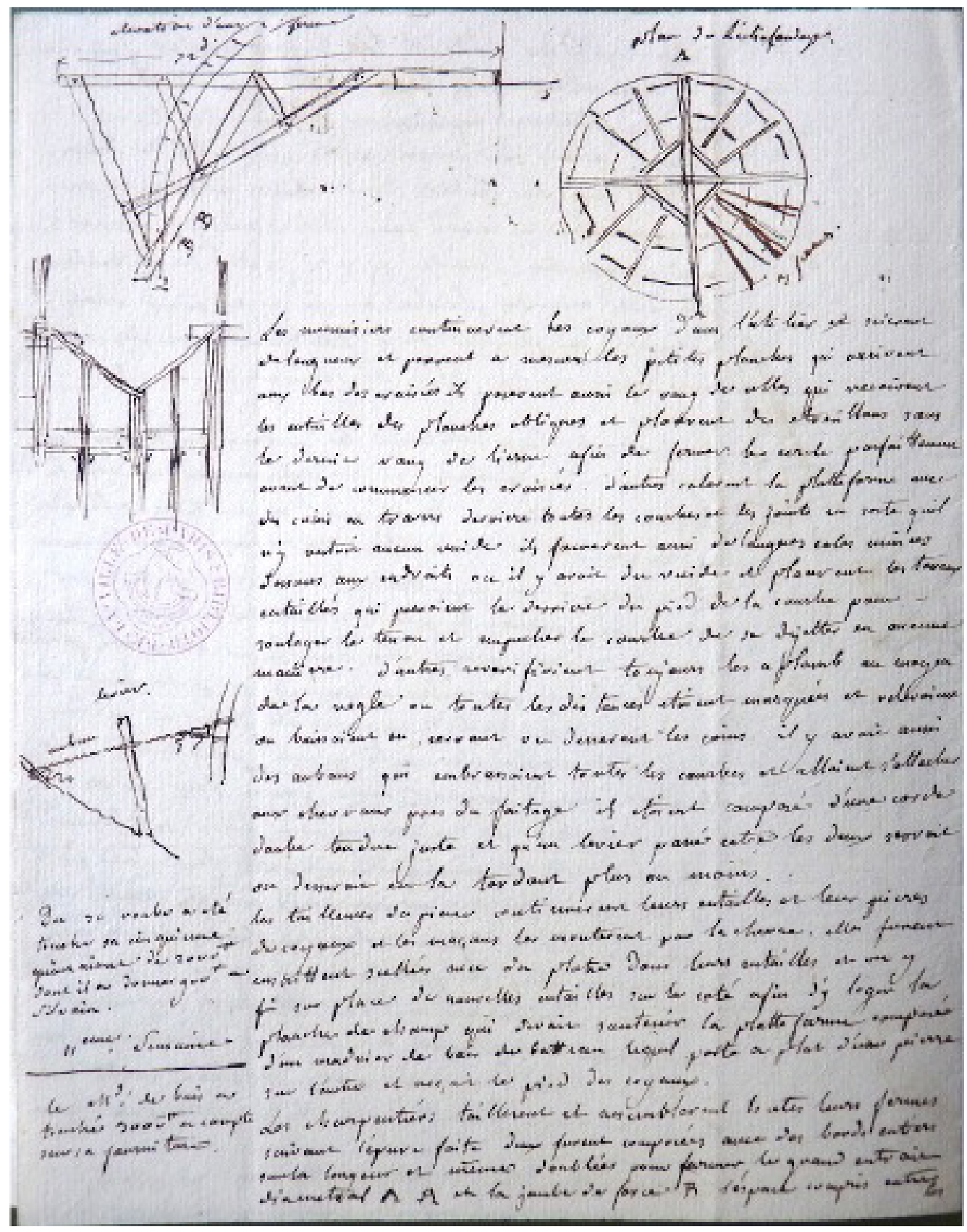

Figure 4. "Notice sur le procédé de la (nouvelle) charpente de la halle au Bled," 1782-1783, BHVP, Ms CP 4823.

pas sur le sol] de réparation seront absolument les mêmes que ceux qu'ils emploirons pour plafonner en volige et quoique très solides, ils sont si simples et si usités qu'ils ne méritent pas d'être décrits," "Réponse aux observations de Mr Moreau architecte du Roy et de la ville sur le projet de couvrir la halle aux grains," n.d., Ms CP 4823, BHVP, Paris. 


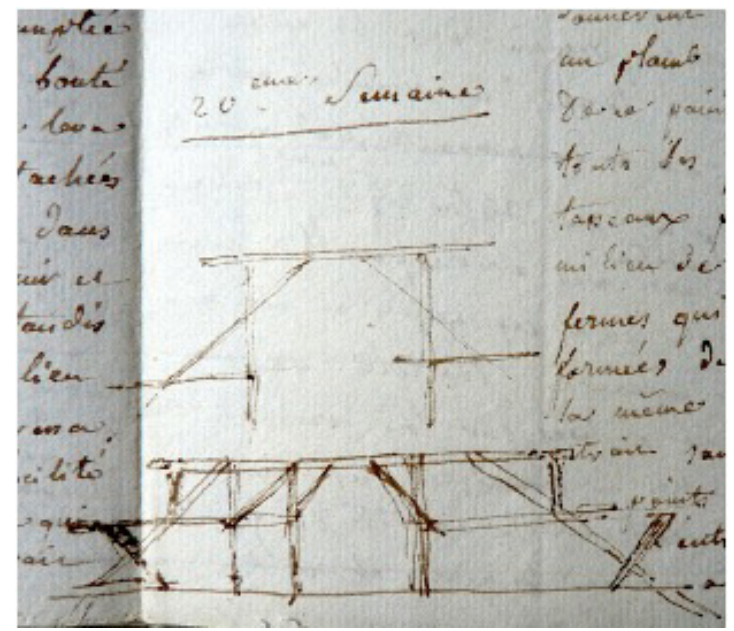

Figure 5. A detail of "Notice sur le procédé de la (nouvelle) charpente de la halle au Bled," 1782-1783, BHVP, Ms CP 4823.

The "Note" shows that the scaffolding was in fact neither simple nor in common use. Not only were several flying scaffolding necessary to erect the plank curves, but the central scaffolding essential for building the lantern, described as "perfectly simple," required a number of new problems to be solved that were linked to the size of the framework: a) to be strong, but at the same time light enough to be easily positioned; b) to save on major timber members so as to reduce cost. For reasons of economy, the scaffolding was not placed on the ground as the architects had proposed, but rested on the cornice. Two points are worth emphasizing here. First, the empirical character of this scaffolding. In order to limit its cost and to lighten it, the architects recommended making it, like the dome, out of planks, but once put in place the main truss (entrait) appeared "of a frightening fragility." It was necessary to reinforce the complete structure to a height of 40 feet $(12.96 \mathrm{~m})$. A letter from the carpenter Albouy, in charge of the central scaffolding, to Molinos, pointing out changes made by the carpenter, confirms that the structure was not entirely designed at the beginning, but that it was the result of trial and error. ${ }^{11}$ Secondly, the lifting of the scaffolding which occupies a large part of the narrative turned out to be just as complex as the design of the scaffolding itself. Because of its exceptional size, weight, and elevated position, the scaffolding was assembled on the ground, then hoisted in parts and re-assembled higher up. Two hoisting devices (chèvres, goats) of over 42 feet (13

11 "You take little account of men of talent, since you seek to reward him so poorly, it was not worth the trouble of applying myself as I have done, in order to be so poorly rewarded, and yet you know that I have been very useful to you, and someone other than me would have let you make mistakes" ("vous Ne faite guere de cas des hommes a talan, puisque vous voules le Recompensé cy mal, il Nest pas la penne de se tant appliqué comme j'ay fait, pour Etre cy mal Recompancé, Cependant vous saves Bien que je vous ay Ete Bien hutille, Et qu'un autre que moy vous auret lesse faire des fautes"), Letter from Albouy to Jacques Molinos, 12 August 1783, Ms CP4823, BHVP, France. 
metres) had to be joined end to end to form devices of 80 feet (26 metres). The "Note" thus reveals what is rarely documented: the design of a process. In his letter, the carpenter points out another operation that is difficult for the historian to grasp, the dismantling of the scaffolding. In his phonetic language, he draws the architect's attention to the essential importance of the chain of command in the various deconstruction operations, comparing the foreman to a "shepherd":

It is not difficult to demolish the whole scaffolding from the top, but for the large one you need a master in charge who knows his trade and how to order his men properly, without which they would look like a flock without a shepherd, and the sheep will throw themselves into the wolf's throat, and in this case the men you could put there, if they are not well [led], they will throw themselves into the abyss, and will be killed and will smash everything. ${ }^{12}$

This metaphor of sheep and wolf and the non-standard spelling (see notes) illustrate the cultural gap between architect and carpenter and the possible difficulty of communication that could result from it.

2. Methods and instruments for ensuring the accuracy of execution. The document reveals the importance of the operations of measurements and verifications (five occurrences for the verb "verifier" (to verify) and thirteen for the verb "revérifier" (to reverify). Accurate determination of measurements such as the horizontal and vertical dimensions of so great a space required adapting measuring tools and methods. The architect describes in minute detail a number of measuring instruments made specifically for these operations: a ruler with a perpendicular plank fixed to it to check the verticality of the walls (Figure 6a); a three-feet double square (Figure 6b). Various devices were invented to ensure the correct position of the timber curves as they were built, such as cables with levers to tighten and loosen ropes and a capstan-like machine used for pulling them into shape (Figure 6c). The architect is particularly interested in the drawing made on the site. The text opens with the preparation of the area to trace the full-scale drawings. The verb tracer (to trace) appears thirty-one times and the word épure (fullscale drawing) eighteen times. Both terms are reserved for execution-size drawings made on the spot. These drawings are made in several places: on the plaster area and on the top of the walls for the main drawings; on the scaffolding and on tables set up in the joiners' workshop for the particular drawings.

The document shows the importance of the full-scale drawings; only one small-scale drawing is mentioned: a plan given to the carpenter to make the wooden platform on which the curves are

12 "Il Nest pas Mal Esé de faire démolir tout lechafaud du haut, mé quand au grand il faud un Maitre En tete, qui connesse Bien son Etat, Et quil sache Bien commandé son monde, sans quoy sa semblera a un troupeau sans Bergé, que les mouton vont se jeté a la guele du loup, Et icy les hommes que vous pourres y Metre sils Ne sont pas Bien, ils se jetteront dans le presipice, Et se tueront Et ils casseront tout," Ibid. 
established. This plan, drawn from the execution-size drawing, turns out to be wrong; a second full-scale plan has to be directly drawn on the top of the walls by the joiner Roubo himself.
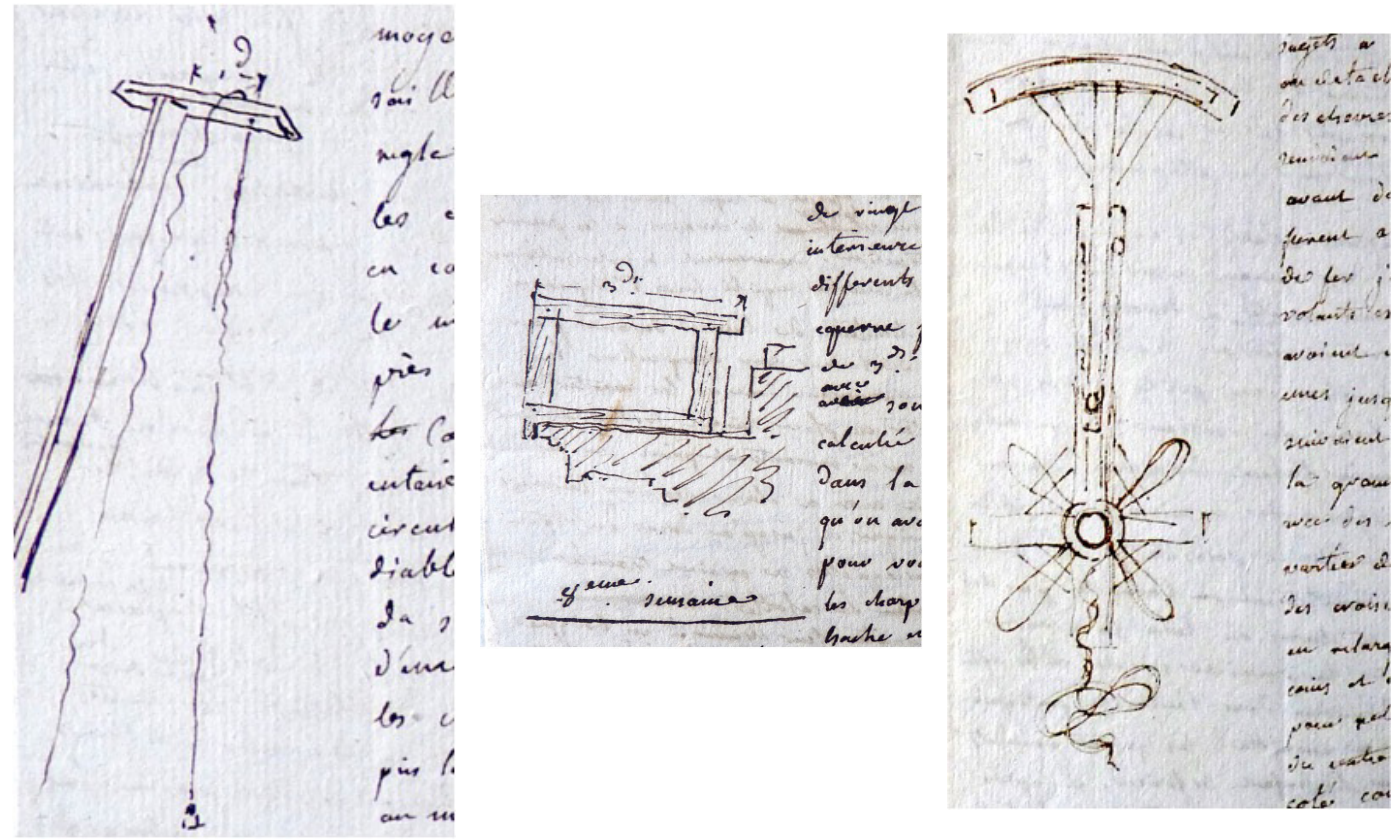

Figure 6. Different instruments for ensuring the accuracy of execution, "Notice sur le procédé de la (nouvelle) charpente de la halle au Bled," 1782-1783, BHVP, Ms CP 4823.

3. Methods and tools for shortening operations and for improving the durability of materials. As the work went on, various methods for shortening operations were also devised. The architect pays special attention to a procedure for accelerating mortises (I reproduce the erasures):

A workman from the workshop called Audry suggested a way consisting of making a mould the size of the mortises, tipping it with an iron bevel, see A, and so mark each mortise or half-mortise with a single blow from the mallet. This operation was found to be a good one and was adopted, and his initiative was rewarded, so as to incite emulation from his colleagues publish his name here as that of a elever man who deserves praise and respeet. ${ }^{13}$

Molinos is also particularly interested in the substances that improved the quality and durability of materials. He notes that soot added to plaster "long resists water" and focuses on the tarring

\footnotetext{
13 "Un ouvrier de l'atelier nommé Audry proposa un moyen qui était de faire un moule de la grandeur des mortaises, de ferrer son extrémité en biseau comme on peut voir en A et de tracer ainsi chaque mortaise ou demi mortaise d'un seul coup de maillet. Ce moyen fut trouvé bon et accepté, et son zèle récompensé afin d'exciter l'émulation parmi ses confrères nous publions, ici son nom comme celui d'un homme intelligent qui mérite et des louanges et des égards," "Note des opérations," Cahier 2, p. 1, Ms CP 4823, BHVP, Paris.
} 
of the timbers in direct contact with the masonry. He remarks the presence of two mariners "whose profession is to tar all the boats in harbour." 14

It is interesting to note that none of these operations are mentioned in the description of the building method published by Philibert De l'Orme. In terms of invention, it can be seen that the main technical problems were not connected to the structure and its assembly but to its positioning. Large numbers of problems due to the dimensions of the site, risks and weather conditions had to be solved as the work progressed.

5. Body performances and feats. One passage is of particular interest. It relates the physical challenges that craftsmen offer each other, between members of the same trade or between carpenters and joiners. The operation of dressing the hoisting devices (chèvres) is particularly delicate. Once the two long chèvres have been erected, a carpenter climbs to the top of one of them to place a wreath (bouquet) on it:

They set up these two chèvres of 80 feet (26 metres) height with two shorter chèvres that had no extensions. Each was held up by four cables tied to the attic mullions and the carpenters placed the wreath (bouquet). This bold act, which amazed some of the audience, sparked off emulation from the workmen and an audacious young joiner climbed to the top of one of the 42 -feet $(14 \mathrm{~m})$ chèvres, slid astride the cable to the casement it was tied to and climbed through. This reckless behaviour was stopped by severe admonishment. ${ }^{15}$

It can be seen from this passage that erecting very tall devices was a particularly difficult operation. All the workmen would be watching and the operation was completed by placing a wreath atop the structure, a ritual that usually marked the topping-out of a building. As the passage suggests, hoisting these devices till they were vertical required considerable physical agility. A much later drawing by Alexandre Steinlen (1859-1923) illustrates the same operation (but on the ground and with a normal-sized chèvre)(Figure 7). One carpenter hanging from a rope uses his weight to lift the device, while another does the same with a lever. Steinlen's two carpenters look more like acrobats or gymnasts than workmen.

\footnotetext{
14 "They acquitted themselves more quickly and effectively in this operation than workmen would have done who did not understand the operation. They also obtained the far more cheaply than building workmen would have done." "Note des opérations," Cahier 2, p. 2, Ms CP 4823, BHVP, Paris.

15 "On mit sur pied ces deux chèvres portant 80 pieds de hauteurs [26 mètres] avec deux autres chèvres moins hautes et sans prolongement. Chacune fut entretenue par 4 aubans attachés dans les trumeaux des greniers et les charpentiers y posèrent le bouquet. Cette hardiesse qui étonna une partie du public mit émulation parmi les ouvriers et un jeune menuisier téméraire montant jusqu'au sommet d'une des chèvres de 42 pieds [près de 14 mètres] se laissa glisser au risque de sa vie le long de l'auban qu'il avait entre les jambes jusqu'à la croisée [fenêtre] ou il était attaché et par où il entra. Ces imprudences furent arrêtées par de sévères réprimandes," "Note des opérations" Cahier 4, p. 3, Ms CP 4823, BHVP, Paris.
} 


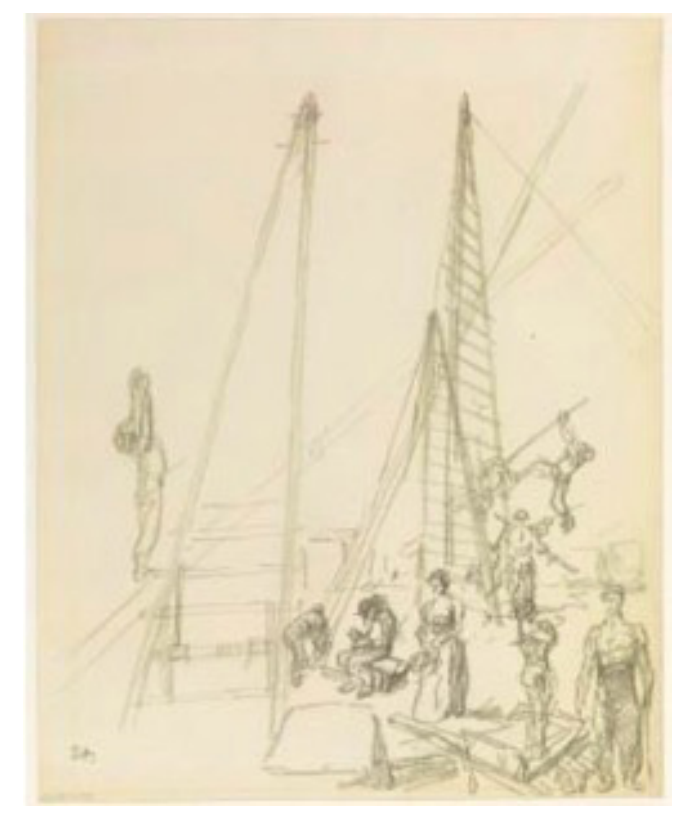

Figure 7. Alexandre Steinlen, Workmen dressing a hoisting device (chèvres) Musée d'Orsay, RF 31828 recto.

Molinos's account and Steinlen's drawing reveal three key aspects of the works carried out on building site, not easily perceived by the historian: the importance of body techniques and feats; ${ }^{16}$ the physical freedom allowed by the changing configuration of the workplace; and the public, almost theatrical, nature of the building site. The carpenter's physical agility required to raise the hoisting devices is completed by a playful feat of a joiner that provokes the admiration and the entertainment of his companions: a "reckless" physical prowess regarded as unnecessary and dangerous by the architect and stopped by "severe admonishment." The modern reader cannot help thinking of the feeling of freedom evoked by carpenters and scaffolders working at great height in the open air and moving from site to site. ${ }^{17}$ It may well be that by their agility and physical daring some workmen might achieve a reputation beyond their own trade. Another key element is the presence of spectators. The scene, writes the architect, amazed une partie du public (some of the audience). This covered the various trades working on the job, and also Parisians. In February 1783, the Mémoires secrets (Secret memoirs) reported that the machines and ingenious scaffolding employed on the building site aroused the "admiration

\footnotetext{
${ }^{16}$ The concept of "body technique" is taken from Marcel Mauss, "Les techniques du corps," in Sociologie et anthropologie (Paris: PUF, 1950), 371.

${ }_{17}$ Michel Parbot, Les Echafaudeurs (Bry-sur-Marne : Institut national de l'audiovisuel, 1965), Newsreel, $8 \mathrm{mn} .55$ s. See Valérie Nègre, ed., L'Art du Chantier. Construire et démolir du XVIe au XXIe siècle (Paris: Snoeck, 2018), 254.
} 
of the crowd." ${ }^{18}$ According to this source the construction of the dome had become a "public spectacle." This shows that the construction site was not only a place of work, it was also a place of representation of the work of men and trade communities.

\section{The actors of the site and the circulation of knowledge}

As we said, the architect describes actions in such a way that it is not possible to know who is giving the orders. The identities of the authors of the process and tools essential for building the structure are hard to establish. Nevertheless, other documents kept in the same archive folder make it possible to specify the role of the master joiner. Roubo does not act as a contractor but as a supervisor of the works. It is important to recall that in the eighteenth century, important building sites were doubly conducted (conduits): on the one hand, by an inspecteur (inspector) employed by the architect; on the other hand, by one or more conducteurs (conductors) employed by the contractor or by each contractor. The architect's inspector oversaw the construction of the building; he inspected the quality and quantity of the materials and supervised their use, according to the proportions and forms determined by the plans and specifications. The artisan "conductor" hired the workers and controlled the execution of the work related to his trade. ${ }^{19}$ The appointment of Roubo as the conductor of the works was therefore not exceptional. Nevertheless, since the construction site was limited to the execution of the wooden dome, it is not clear whether the architect or the joiner was in charge of the supervision of the whole operation. In the draft of a letter to the Journal de Paris, the architects significantly hesitate between calling him "inspector" or "conductor." I reproduce the erasures that reveal their embarrassment and the ambiguous status of the craftsman: "[Roubo] has preferred to be the inspector, the main conductor for an honest and fixed profit rather than to become the contractor of the whole joinery by a block deal. ${ }^{20}$ It is important to bear in mind that Roubo was a more renowned practitioner than the two architects. If Legrand and Molinos occupied a hierarchical position clearly superior to that of the joiner, the latter, placed under their command, enjoyed a greater visibility, which gave him authority in his field. In the 1780s, Roubo, was well known among Paris savants. ${ }^{21}$ Some ten years earlier, the Academy

${ }^{18}$ Louis Petit de Bachaumont, Mémoires secrets pour servir à l'Histoire de la République des Lettres, 4 février [1783], vol. XII, p. 68.

19 For a socio-economic approach to building sites at the end of the eighteenth century, see Allan Potofsky, Constructing Paris in the Age of Revolution (New York: Palgrave Macmillan, 2009).

20 The draft reads: "On doit encore cette justice au Sr Roubo qu'il a refusé d'être entrepreneur de sa menuiserie dans a été lui même au devant des vues d'économie que les architectes ont désiré mettre dans cet ouvrage et qu'il a préféré en être l'inspecteur, le conducteur principal moyennant un bénéfice honnête et fixe plutôt que de devenir l'entrepreneur de toute la menuiserie par un marché en bloc..." "Note pour le journal 22 septembre 1783," CP 4823, BHVP, Paris.

${ }^{21}$ Bruno Belhoste, "A Parisian Craftsman among the Savants: the Joiner André-Jacob Roubo (17391791) and his Works," Annals of Science 69, no. 3 (2012): 395-411. See also Valérie Nègre, L'Art et la 
of Sciences had agreed to publish his treatise on joinery in the prestigious collection of the Description des Arts et Métiers (1761-1788). Major journals had extensively covered its volumes as they appeared in 1769, 1771 and 1782. The craftsman's skills were regularly noted. In 1769, Le Journal des Beaux-arts et des Sciences considered his treatise to be "as perfect in its genre, as accurate in detail and, of course, in its form and overall, as all those that have been published on other crafts by the Royal Academy of Sciences." 22 Roubo embodied the ideal craftsman promoted by the royal administration and the Encyclopedists. He had taken architecture lessons in parallel with his apprenticeship and could read, write, draft and even engrave. It was via such intermediaries, able to bring together savants and workmen - two classes who did not speak the same language - that the savants would be able to apply their knowledge to the world of crafts and thus improve them. In addition to his tomes on joinery, in 1777 Roubo published an ambitious book on the construction of theatres. A number of journals praised his proposals for a theatre that would be safe, airy and tasteful. ${ }^{23}$ Roubo was indeed the ideal figure of the craftsman useful to his nation. ${ }^{24}$

It follows from these considerations that Molinos may have chosen the impersonal form to avoid mentioning the management of the works. Several documents suggest that he intended to circulate his "Note" and perhaps to publish it. Some passages of the text are included in different Mémoires addressed to the Royal Academy of Architecture or other institutions. His concern was certainly to demonstrate his technical knowledge to his intended readership (academicians, members of the administration) in order to increase his reputation and to obtain other commissions. The purpose of the writing influences what he says and what he doesn't say (who supervises and commands). This would explain why it does not describe daily operations such as material registration and weighing, for example.

In this light, the "Note" would document a transfer of knowledge from craftsmen to architects, but a transfer masked by the use of impersonal verbs. It must be stressed that there is no evidence of exchange in both directions. The narrative does not allow us to understand whether the joiner Roubo or the carpenter Albouy learn from the architect. In other words, one cannot deduce from the "Note" that the building site was a trading zone.

matière. Les artisans, les architectes et la technique (1770-1830) (Paris: Classiques Garnier, 2016).

22 "aussi parfait dans son genre, aussi exact pour les détails, \& aussi bien entendu pour la forme $\&$ pour l'ensemble, que tout ceux qui ont été publiés sur d'autres Arts par l'Académie Royale des Sciences," in "L'Art du Menuisier. Première Partie. Par M. Roubo le Fils, Compagnon Menuisier," Journal des Beaux-arts et des Sciences (July 1769): 123-4.

${ }^{23}$ André Jacob Roubo, Traité de la construction des théâtres et des machines théâtrales (Paris: Cellot \& Jombert, 1777). “Traité de la construction des Théâtres et des machines théâtrales," L'Esprit des Journaux (November 1777): 121-35.

${ }^{24}$ In 1769 , Le Journal des Sçavans considered him to be "an object of emulation for all craftsmen able to follow his example and rise by their talent above their social position," "L'Art du Menuisier, par M. Roubo le fils, Compagnon Menuisier," Le Journal des Sçavans (May 1769): 424. 


\section{Conclusion}

The most remarkable aspect of the "Note" is that it offers clear evidence of the continual adaptations and micro-inventions that occurred on building sites. As I have said, the building site of the Halle au Blé was no ordinary one. But we know that such micro-inventions could also result from ordinary works. ${ }^{25}$ Determining what was due to whom is a difficult task because the objects and operations being discussed are ephemeral. Who was the author of the dome of the Halle au Ble? Who was the "inventor" of the construction process (De l'Orme)? Who were the architects who had the idea to revive it (Legrand and Molinos)? A letter published in the Journal de Paris in September 1783 indicates that their idea did not come, as they claimed, from De l'Orme's treatise, but from a project a merchant in Tours had commissioned from a joiner in 1777. A document in Molinos's papers confirms that he had procured the estimate and model for this construction. The idea of the structure had, therefore, at least three "authors": De l'Orme, the merchant (and the joiner) who applied the construction process in Tours, and Legrand and Molinos who applied it in Paris. It should be added that at no point did Roubo, despite having erected a similar structure near Versailles some years earlier, attempt to present himself as joint author of the wooden cupola. In the early 1840s, the architect-joiner Louis Auguste Boileau (1812-1896), a renowned promoter of metal architecture, claimed that the author of the dome was Roubo and accused "Paris historians" of omitting his name. ${ }^{26}$ This view of a former joiner may be treated with some scepticism, but he does ask a question that few historians have addressed: who is the author of a complex technical object? Although the story of the construction of the dome is well known, the question of the contribution of the various participants to its design had escaped scholar's attention. While historians of architecture give credit to the idea that it was the work of the architects Legrand and Molinos, ${ }^{27}$ the historian of science and technology Bruno Belhoste considers it to be due to the master joiner Roubo. ${ }^{28}$

The case of the building site of the Halle au Blé shows us why it is simplistic to consider only the finished artefact. Historians should attend more to the creativity and skill that go into "making things work." With respect to scaffolding, not only are its successful design and construction for a specific project crucial, but also its successful dismantling or removal, which also present challenges. The historian must pay attention to what has disappeared, and make

\footnotetext{
${ }^{25}$ Philippe Bernardi, "Essai, tâtonnement et pari: le rôle de l'individu dans l'innovation," Médiévales 39 (2000): 14-29.

26 [Louis Auguste Boileau], “ Roubo,” Annuaire de la Société Montylon et Franklin (1835).

27 Marc Deming, La Halle au blé, and Daniel Rabreau, "Le Relativisme du renouveau classique dans l'architecture des Lumières," in Architecture et théorie. L'héritage de la Renaissance, ed. Jean-Philippe Garric, Frédérique Lemerle and Yves Pauwels, http://inha.revues.org/3422.

${ }^{28}$ See Belhoste, "A Parisian Craftsman," and Belhoste, Paris savant. Parcours et rencontres au temps des Lumières (Paris: Colin, 2011).
} 
perceptible ephemeral objects and methods, physical techniques and the ingenious organisation of operations.

\section{Acknowledgements}

I thank Francesca Bray for her close re-reading and to Roger Depledge for the English translation.

\section{Competing interests}

The author has declared that no competing interests exist. 